\title{
Trinexapac-EThyl AND Sulfometuron-Methyl Selectivity to Young Eucalyptus Plants ${ }^{1}$
}

\author{
Seletividade de Trinexapac-Ethyl e Sulfometuron-Methyl para Plantas Jovens de Eucalipto
}

\author{
CORREIA, N.M. ${ }^{2}$, and VILLELA, G.B. ${ }^{3}$
}

\begin{abstract}
Trinexapac-ethyl and sulfometuron-methyl are the most widely used ripeners in sugarcane. The application is performed by airborne spraying. Thus, if weather conditions are unfavorable, spray drift to neighboring areas may occur. The objective of this study was to assess the selectivity of the plant growth regulators trinexapac-ethyl and sulfometuronmethyl, used as sugarcane ripeners, to eucalyptus (Eucalyptus urograndis) young plants. The experiment was installed in an eucalyptus commercial yield area, in the municipality of Tambaú, state of São Paulo, Brazil, and arranged in a $2 \times 8$ factorial design in randomized blocks with four replications. The treatments studied were trinexapac-ethyl and sulfometuronmethyl, sprayed in eight doses, $0 ; 1.0 ; 2.5 ; 5.0 ; 10 ; 25 ; 50$ and $100 \%$ of the dose used in sugarcane as ripeners (200 $\mathrm{g} \mathrm{ha}^{-1}$ of trinexapac-ethyl and $15 \mathrm{~g} \mathrm{ha}^{-1}$ of sulfometuron-methyl). Chemical ripeners were applied on eucalyptus plants with $48 \mathrm{~cm}$ in height on average; 10.1 branches; $4.5 \mathrm{~mm}$ of stem diameter and $44.3 \mathrm{~cm}$ of crown diameter, at 46 days after seeding. Trinexapac-ethyl was selective to eucalyptus and stimulated crown diameter growth. At higher doses, sulfometuron-methyl promoted severe noticeable injuries in eucalyptus plants, such as apical bud death. However, during the assessment period the plants recovered and the visual symptoms of phytotoxicity and growth alterations were not observed at 60 days after application. The plant growth regulators trinexapac-ethyl and sulfometuron-methyl were selective to eucalyptus young plants.
\end{abstract}

Keywords: Eucalyptus urograndis, phytotoxicity, ripener.

\begin{abstract}
RESUMO - Entre os maturadores, o trinexapac-ethyl e o sulfometuron-methyl são os mais usados nos canaviais. A pulverização é aérea, de modo que, se as condições meteorológicas não forem favoráveis, poderá ocorrer deriva para culturas vizinhas. Assim, objetivou-se neste trabalho avaliar a seletividade dos reguladores vegetais trinexapac-ethyl e sulfometuron-methyl, utilizados como maturadores em cana-de-açúcar, para plantas jovens de eucalipto (Eucalyptus urograndis). $O$ experimento foi instalado em área de produção comercial de eucalipto, no municipio de Tambaú, SP, Brasil. O delineamento experimental foi o de blocos ao acaso, em esquema fatorial $2 \times 8$, com quatro repetições. Os tratamentos estudados foram trinexapac-ethyl e sulfometuron-methyl, pulverizados em oito dosagens: $0 ; 1,0 ; 2,5 ; 5,0 ; 10 ; 25 ; 50 ;$ e 100\% da dose utilizada em cana-de-açúcar como maturador (200 $\mathrm{g} \mathrm{ha}^{-1}$ de trinexapac-ethyl e $15 \mathrm{~g} \mathrm{ha}^{-1}$ de sulfometuron-methyl). Os reguladores de crescimento foram aplicados sobre as plantas de eucalipto com $48 \mathrm{~cm}$ de altura, 10,1 ramos, 4,5 $\mathrm{mm}$ de diâmetro de caule e 44,3 cm de diâmetro de copa, aos 46 dias após o plantio. O trinexapac-ethyl foi seletivo para o eucalipto e estimulou o crescimento do diâmetro de copa. Já o sulfometuronmethyl, nas maiores doses testadas, ocasionou injúrias visuais severas às plantas de eucalipto, como a morte de gemas apicais. Contudo, no decorrer das avaliações, as plantas recuperaram-se, não sendo observados sintomas visuais de fitointoxicação ou alteração do crescimento aos 60 dias após a aplicação. Os reguladores vegetais trinexapac-ethyl e sulfometuron-methyl foram seletivos para plantas jovens de eucalipto.
\end{abstract}

Palavras-chave: Eucalyptus urograndis, fitointoxicação, maturador.

Recebido para publicação em 24.9.2014 e aprovado em 26.1.2015.

Embrapa, Brasília-DF, Brasil; <nubia.correia@embrapa.br>; ${ }^{3}$ Monsanto Brasil, Petrolina-PE, Brasil. 


\section{INTRODUCTION}

The growing demand for mechanized areas for sugarcane cultivation is making available areas with lesser capacity for other types of farming, such as planted forests. These are expanding and have great yield potential, in particular the one of eucalyptus, an exotic species from Australia that was introduced in Brazil around 1869 and has adapted very well to the country's climatic conditions (Remade, 2013). Eucalyptus plantations have become very common due to their high adaptability and high growth rate; regardless of scale, they ensure an extra income (Agrianual, 2013). In 2012 , the area planted with eucalyptus in the country was 5.1 million hectares (ABRAF, 2013).

On the other hand, the relationship promoted between the sugarcane and eucalyptus crops requires attention to factors that can negatively influence some of them (Agrianual, 2013), such as the risk of drift or even error in the application of products used as ripeners in sugarcane on eucalyptus plantations.

The ripeners are defined as plant growth regulators and act by changing the morphology and physiology of the plant, leading to qualitative and quantitative changes in the yield. These products can act to promote the reduction of plant growth, enabling increments in sucrose content in internodes, early ripening, increase the sugar yield, and also act on the enzyme (invertases) which catalyze the accumulation of sucrose in the culms (Castro, 1999; Dalley \& Richard Júnior, 2010).

Spraying of the ripeners in the sugarcane fields is airborne, so that if the weather conditions are not favorable, drift may occur to neighboring crops (Correia \& Leite, 2012). This can cause serious damage to sensitive plants, especially if the product applied is sulfometuron-methyl, which is a sulphonylurea, an inhibitor of acetolactate synthase (ALS), with potential herbicide at higher dosages. However, depending on the phytotoxic action of the growth regulator, even at low concentrations it can promote injury to plants (Correia \& Leite, 2012). Much of the claims arising from the application of pesticides in sugarcane is due to the contamination of neighboring areas for products used as ripeners.

Among the ripeners, trinexapac-ethyl and sulfometuron-methyl are the most used in the sugarcane fields. Thus, it is necessary to assess their phytotoxicity levels on agricultural crops with potential use in areas neighboring sugarcane. With the hypothesis that phytotoxicity caused by plant growth regulators to eucalyptus plants is dependent on the dosage and the product used, with sulfometuron-methyl being more phytotoxic than trinexapac-ethyl, this study was carried out.

Therefore, this study aimed to assess the selectivity of growth regulators trinexapacethyl plant and sulfometuron-methyl, used as ripeners in sugarcane for eucalyptus seedlings (Eucalyptus urograndis).

\section{MATERIALS AND METHODS}

The experiment was installed in a commercial area of eucalyptus on farm Fazenda Boa Vista in the municipality of Tambaú, SP, from November 2012 to March 2013.

The geographical coordinates of the experimental area are: south latitude $21^{\circ} 36^{\prime} 19,47^{\prime \prime}$ and west longitude 47¹3'24,93", with an altitude of $849 \mathrm{~m}$. The climate is humid temperate with dry winter and temperate summer (Cwb), according to Köppen classification.

The seedlings (GG100 clone) were planted on $11 / 29 / 2012$, spaced $3.0 \mathrm{~m}$ between rows and $2.0 \mathrm{~m}$ between plants. Each plot consisted of $1.0 \mathrm{~m}$ wide (application range in the eucalyptus row) and $10.0 \mathrm{~m}$ long (five plants), totaling $10.0 \mathrm{~m}^{2}$. At the time of application of the products, at 46 days after planting (DAP), the eucalyptus plants had an average height of $48 \mathrm{~cm}(34-69 \mathrm{~cm}), 10.1$ branches (4-16), $4.5 \mathrm{~mm}$ in diameter of stem (2 to $9 \mathrm{~mm}$ ) and $44.3 \mathrm{~cm}$ of crown diameter (from 10 to $65 \mathrm{~cm}$ ).

The experimental design was a randomized block in the $2 \times 8$ factorial arrangement, with four replications. The treatments studied were two plant growth regulators, trinexapac-ethyl and sulfometuron-methyl, sprayed in eight dosages: $0 ; 1.0 ; 2.5 ; 5.0 ; 10 ; 25 ; 50$; and $100 \%$ 
of the dose used in sugarcane as a ripener (200 $\mathrm{g} \mathrm{ha}^{-1}$ of trinexapac-ethyl and $15 \mathrm{~g} \mathrm{ha}^{-1}$ of sulfometuron-methyl). To the spray of sulfometuron-methyl was added $0.1 \%$ surfactant.

The commercial products used were Moddus ${ }^{\circledR}$ (trinexapac-ethyl), Curavial ${ }^{\circledR}$ (sulfometuron-methyl) and Agral ${ }^{\circledR}$ (surfactant).

Growth regulators were applied on eucalyptus plants on $01 / 14 / 2013$, between 10:40 - 12:00 hours. A backpack sprayer was used, at a constant pressure (maintained by compressed $\mathrm{CO}_{2}$ ) of $4.0 \mathrm{kgf} \mathrm{cm}^{-2}$, equipped with a bar with two flat spray tips ("fan") TT 110015 , spaced $0.5 \mathrm{~m}$, with liquid consumption equivalent to $200 \mathrm{~L} \mathrm{ha}^{-1}$. At the time of the application, the relative humidity ranged from $78 \%$ to $73 \%$; the temperature of the air ranged from $23.8^{\circ} \mathrm{C}$ to $24.5^{\circ} \mathrm{C}$; the soil temperature ranged from $22.2{ }^{\circ} \mathrm{C}$ to $23.4{ }^{\circ} \mathrm{C}$; the wind speed ranged from 5.9 to $5.2 \mathrm{~km} \mathrm{~h}^{-1}$; cloudiness was $100 \%$; and the soil was moist.

Possible visual damage on the eucalyptus plants were assessed at 8, 15, 30 and 60 days after application (DAA) of the products, assigning scores from 0 to $100 \%$, where 0 represents the absence of noticeable damage and 100 represents the plant death (SBCPD, 1995).

On the day of the application and at 15, 30, 45 and 60 DAA the plant height and stem and crown diameter were measured; on the day of the application and at 30 and 60 DAA, the number of branches per plant was counted. These assessments were performed in the three central plants of each plot, with the aid of a caliper and a ruler.

For plant height $(\mathrm{cm})$ the distance from the base of the plant to the apical bud insertion was measured. Regarding the crown diameter $(\mathrm{cm})$, the distance between the buds from one end to the other of the plant crown was considered. The stem diameter $(\mathrm{mm})$ of the plants was measured at a distance $25 \mathrm{~cm}$ from the ground. The lateral branches were counted from the first branch emerged, considering all the others arising from the main stem.

The data of height, number of branches and stem and crown diameter were adjusted for: value obtained at the time of assessment
$(15,30,45$ and 60 DAA) minus the value obtained on the day of application (0 DAA). The plants did not show a uniform development, and this could interfere with the analysis and interpretation of the results obtained.

The data were submitted to the F test of the analysis of variance. The effects of the dosages, when significant, were compared by polynomial fit of the data, and the growth regulators, when significant, by the Tukey test at 5\% probability. When the interaction was significant, the choice was for the deployment of the doses within each growth regulator, and the effects were compared by polynomial fit of the data.

\section{RESULTS AND DISCUSSION}

The single factors and the interaction of these were significant for phytotoxicity ratings at 8, 15 and 30 DAA. The trinexapac-ethyl did not cause visually perceived damage to the eucalyptus plants even at the highest dose tested (Figure 1). For sulfometuron-methyl, the symptoms intensified with increasing dosage, with polynomial fit of the data at 8 and 30 DAA and the linear at 15 DAA.

The symptoms of phytotoxicity caused by the dosages of $5 \%$ and $10 \%$ of sulfometuronmethyl were small spots of purple color in the leaves with a low frequency. The same symptom was observed in the plants treated with $25 \%$ of the dosage, but in a larger amount and with larger diameter spots, in addition to the occurrence of some necrotic buds. With $50 \%$ of the dose, the symptoms intensified, mainly for the occurrence of necrotic apical buds. These effects have evolved with increasing dosage to $100 \%$, and the coalescence of spots on the leaves was found, making them completely purple, besides the increased mortality of the apical buds. On the other hand, symptoms of phytotoxicity in eucalyptus were not observed at 60 DAA, even in the plants treated with the highest dosage, due to their recovery. Possibly, over time, sulfometuron-methyl was metabolized by the plants in non-toxic metabolites (Anderson \& Swain, 1992).

The regulator versus dosage interaction was significant for crown diameter of the 
eucalyptus plants at 15,30 and 45 DAA (Figure 2). At $15 \mathrm{DAA}$, for sulfometuronmethyl, the data were adjusted in the polynomial form, increasing the dosage of the product, and at 30 DAA there was a linear reduction, obtaining the smaller values with $100 \%$ of the recommended dose. In these two
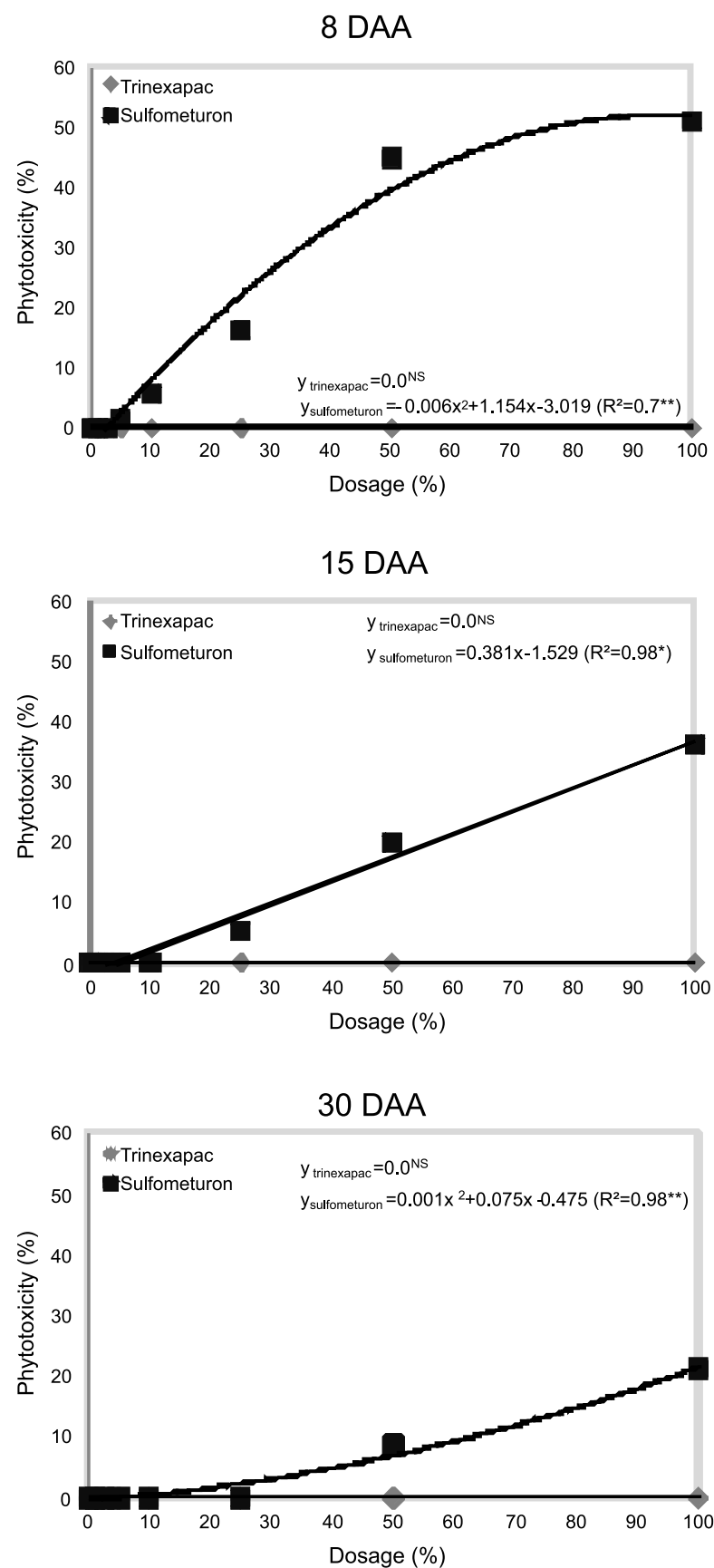

Figure 1 - Intoxication (\%) of the eucalyptus plants at 8, 15 and 30 days after application (DAA) of different doses of plant regulators trinexapac-ethyl and sulfometuron-methyl. assessment periods, there was no significant difference between the doses of trinexapacethyl. However, at 45 DAA, there was a linear
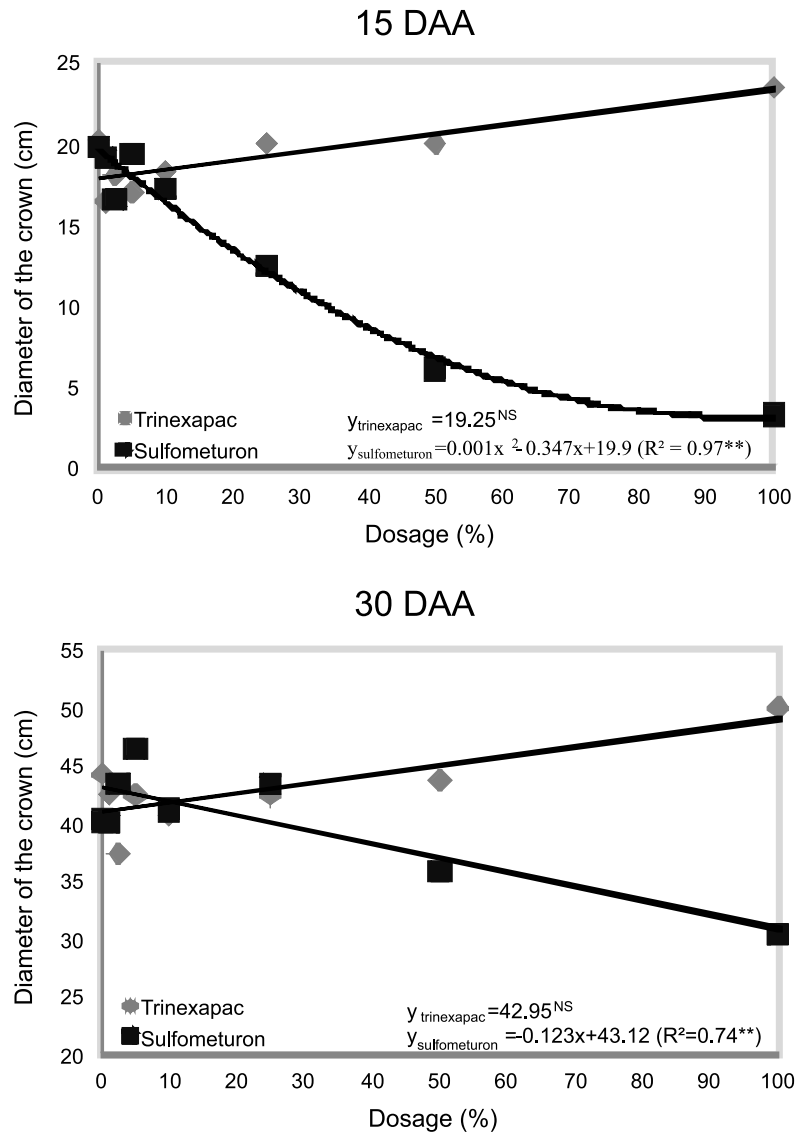

45 DAA

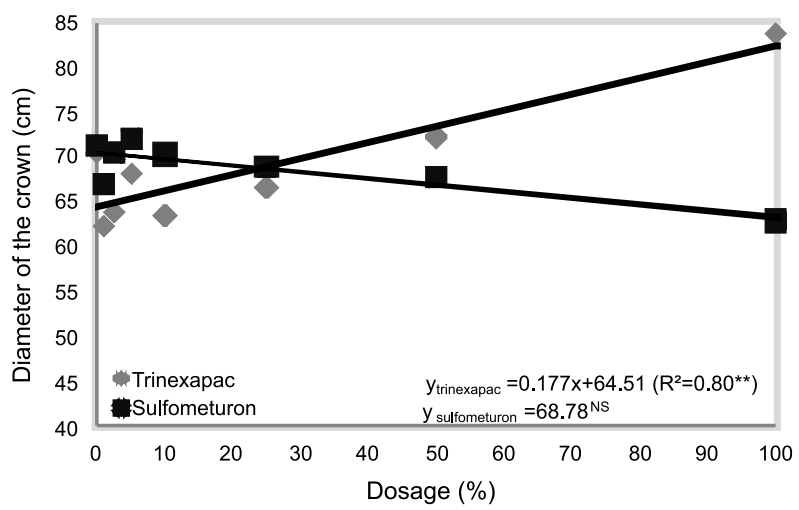

1/ Data for crown diameter adjusted for: value obtained at the time (15, 30 and 45 DAA) of assessment minus the value obtained on the day of the application (0 DAA).

Figure 2 - Crown diameter ${ }^{1 /}$, in $\mathrm{cm}$, of the eucalyptus plants at 15,30 and 45 days after application (DAA) of different doses of plant regulators trinexapac-ethyl and sulfometuronmethyl. 
increase in the growth of crown diameter with increasing dosage of trinexapac-ethyl. As for the plants treated with sulfometuron-methyl, there was no significant effect of the tested dosages. At $60 \mathrm{DAA}$, the single factors or the interaction of these did not significantly affect the diameter of plants crown.

The growth regulators and the regulatory versus dosage interaction were significant for plant height only in the assessment performed at 15 DAA. The trinexapac-ethyl did not affect this variable, regardless of the dosage used (Figure 3). However, the plant growth in height linearly reduced with increasing dosage of sulfometuron-methyl.

For stem diameter and number of lateral branches per plant there was a significant effect of the regulatory versus dose interaction at 15 and $30 \mathrm{DAA}$, respectively. Trinexapacethyl, even at the highest dose sprayed, did not affect negatively the issuance of new branches in the eucalyptus plants or the growth of stem diameter of the plants. However, for sulfometuron-methyl, the data were fit in the polynomial form (for the number of branches) and linear (for stem diameter growth) with increasing dosage, resulting in a lower average with $100 \%$ of the recommended dose. At 45 and 60 DAA, the single factors or the interaction of these did not affect significantly these variables.

The results obtained in this study reinforced the hypothesis that sulfometuronmethyl is more phytotoxic than trinexapacethyl for eucalyptus, and its toxic effect depends on the applied dose. This variability can be explained by the mode of action of the products in the plant and also by the plant ability to metabolize or detoxify the product.

Sulfometuron-methyl belongs to the chemical group of the sulfonylureas and has a primary site of action to the inhibition of acetolactate synthase (ALS) or aceto hydroxy acid synthase (AHAS), affecting the synthesis of essential amino acids valine, leucine and isoleucine (Cox, 2002; Zhou et al., 2007). Furthermore, sulfometuron-methyl may interfere with photosynthesis of the plants by reducing the levels of carotenoids (Meschede et al. (2011). In the US, this product is used as a herbicide in forests and non-agricultural
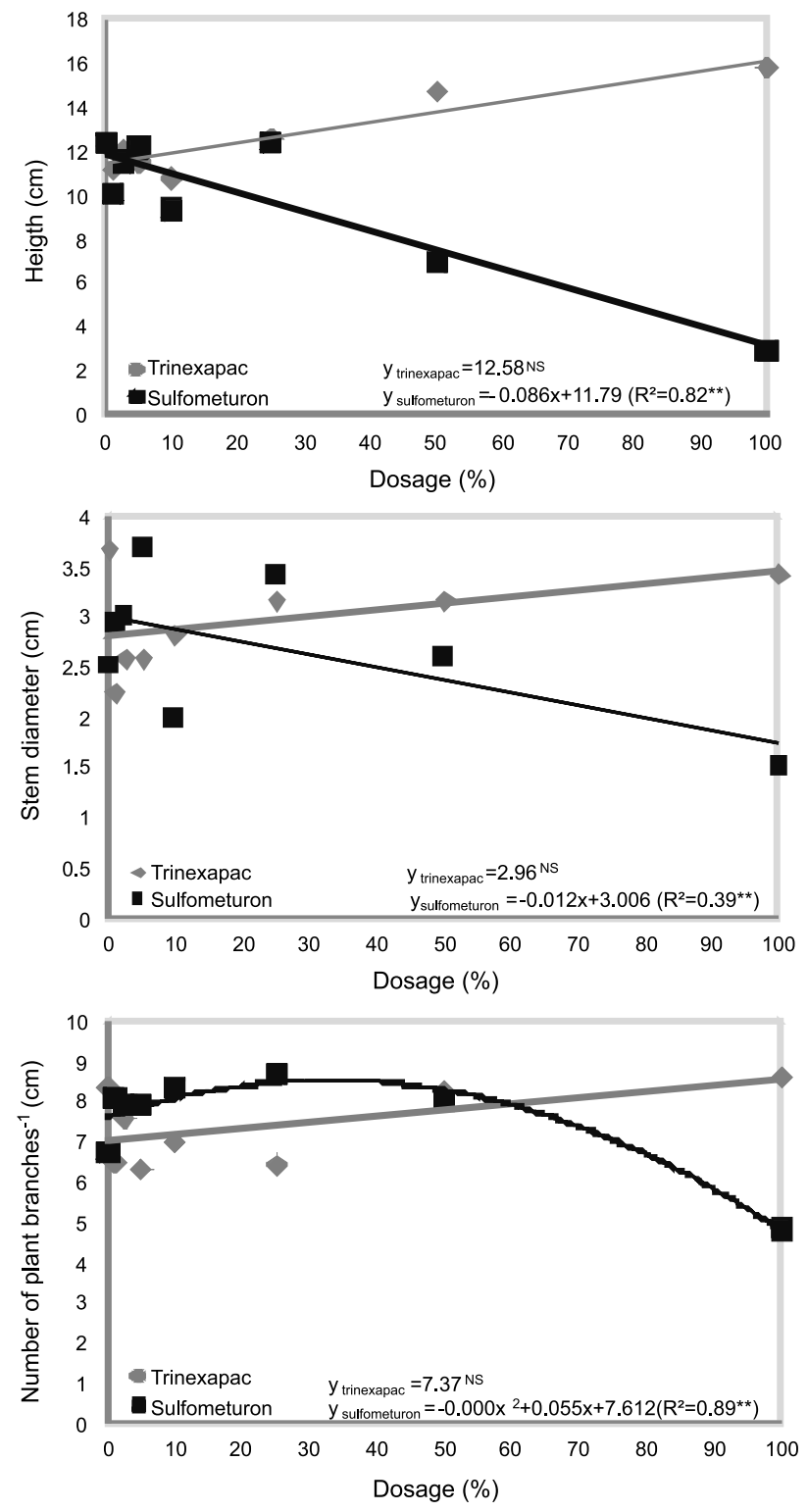

1/ Data adjusted for: value obtained at the time of assessment (15 and 30 DAA) minus the value obtained on the day of the application (0 DAA).

Figure 3 - Stem height ${ }^{1 /}$ and diameter of eucalyptus plants at 15 days after application (DAA) of different doses of plant regulators trinexapac-ethyl and sulfometuron-methyl, besides the number of lateral branches per plant at 30 DAA.

areas, with much higher dosages (above $52.5 \mathrm{~g} \mathrm{ha}^{-1}$ ) (Ahrens, 1994) than those employed in Brazil as growth regulator in sugarcane (20 $\left.\mathrm{g} \mathrm{ha}^{-1}\right)$ (Curavial, 2014).

The phytotoxic effects of sulfometuronmethyl in some plant species have already 
been reported. Of the five species of conifers (Thuja occidentalis, Pinus nigra, Juniperus virginiana, Pinus sylvestris and Pinus strobus) tested, only $T$. occidentalis had some tolerance to sulfometuron-metryl; the others were severely affected by the product (Geyer \& Long, 1998). When assessing the application of sulfometuron-methyl (from 0 to $15 \mathrm{~g} \mathrm{ha}^{-1}$ ) on potatoes, Novo \& Miranda Filho (2006) found that with increasing dose there was a reduction in fresh pasta of normal tubers and of the total tubers and increase in fresh mass of abnormal tubers. Furthermore, sulfometuron-methyl residues in the soil from 240 parts per trillion (ppt) resulted in potato tubers deformation such as cracks and folds (Hutchinson et al., 2007).

In another study, soybean plants treated with $5.25 \mathrm{~g} \mathrm{ha}^{-1}$ of sulfometuron-methyl had a significant reduction in weight and number of seeds and in the mass and number of pods (Pfleeger et al., 2011).

In another study, sulfometuron-methyl, at doses of 7.5 and $15 \mathrm{~g} \mathrm{ha}^{-1}$, caused noticeable severe injuries to peanut, cotton, beans, sunflower, soybean and grape plants, damaging plant development (Correia \& Leite, 2012). However, coffee, citrus, cassava and rubber plants, even when exposed to $15 \mathrm{~g} \mathrm{ha}^{-1}$ of sulfometuron-methyl did not show visual symptoms of phytotoxicity. Changes related to uptake, translocation, site of action, metabolism or even compartmentalization of sulfometuron-methyl by the plants may explain the response variability of the species to the action of the product (Correia \& Leite, 2012).

In this study, trinexapac-ethyl did not cause noticeable damage to eucalyptus plants and did not negatively affect plant growth, even at the highest dose tested. This result was also confirmed by Correia \& Leite (2012) in peanut, cotton, potatoes, coffee, citrus, sunflower, cassava, rubber, soybeans and grapes plants treated with trinexapac-ethyl, at the dosages of 100 and $200 \mathrm{~g} \mathrm{ha}^{-1}$.

Trinexapac-ethyl is an acylcyclohexanedione (Radamacher, 2000; Caldas et al., 2009) that in poaceae species such as wheat, barley and rice, causes reduction in internode length and thus plant height, being favorable to avoid their layering (Zagonel \& Fernandes, 2007; Espindula et al., 2009; Nascimento et al., 2009; Moddus, 2014). This effect can be explained by the mode of action of trinexapac-ethyl, which acts on the metabolism of gibberellins synthesis from $\mathrm{GA}_{12}$-aldehyde, a hormone that, among other functions, promotes cell elongation (Radamacher, 2000; Caldas et al., 2009; Dalley \& Richard Júnior, 2010). In response, the plants have difficulty forming active gibberellins and begin to synthesize and accumulate gibberellins biologically that less efficient, causing reduction in cell elongation (Radamacher, 2000; Taiz \& Zeiger, 2010). In the dicotyledonous species such inhibition is not pronounced, justifying the selectivity of trinexapac-ethyl for them (Radamacher, 2000).

Besides the anti-layering effect of cereals and increased yield of sucrose from sugarcane, the gibberellin synthesis inhibitors promote growth retardation and flowering of grasses (Costa et al., 2009) and regulate flowering of deciduous fruit plants.

In this regard, Mouco et al. (2010) found that trinexapac-ethyl sprayed at high dosages per plant (1.0 g or sequential of 0.5 plus $0.5 \mathrm{~g}$ ) was effective in regulating the plant growth of branches of seedlings of Tommy Atkins mango trees. This effect would not have been observed in the field simply by the occurrence of drift due to the low concentration per plant seen in this situation. When considering a population of 300,000 plants per hectare, as in soybean crops, the equivalent concentration per plant would be 0.33 and $0.67 \mathrm{mg}$ per plant, spraying them directly with 100 or $200 \mathrm{~g} \mathrm{ha}^{-1}$ of trinexapac-ethyl, respectively. These values are much lower than the concentrations tested in fruit plants for retardation of vegetative growth and consequent management of floral induction.

When assessing the application of trinexapac-ethyl, the dosages of 75 to $300 \mathrm{~g}^{\text {ha-1 }}$ in plants of Crotalaria juncea in full vegetative growth, Kappes et al. (2011) stated that the plants height decreased with increasing doses, while the number of branches per plant increased with increasing dosages. The final plant population, the number of seeds per pod and the weight of a thousand seeds were not affected by the application of the growth regulator. 
Correia \& Leite (2012) considered trinexapac-ethyl in the doses of 100 and $200 \mathrm{~g} \mathrm{ha}^{-1}$ as safe for airborne applications in sugarcane, not posing a risk to species peanuts, cotton, potatoes, coffee, citrus, sunflower, cassava, rubber, soybeans and grapes, even with the occurrence of drift or technical failures during product application.

The results indicated that trinexapac-ethyl was selective for the eucalyptus plants and stimulated the growth of the crown diameter. As for sulfometuron-methyl, in the largest doses tested it caused severe noticeable injuries to the eucalyptus plants, like the death of the apical buds. However, during the assessments, the plants recovered with no noticeable visual symptoms of phytotoxicity or abnormal growth at 60 DAA.

\section{LITERATURE CITED}

ABRAF. Anuário estatístico ABRAF 2013 ano base 2012. Brasília: 2013. 148 p.

AGRIANUAL: Anuário da agricultura brasileira. São Paulo: Informa Economics FNP, 2013. 480 p.

ANDERSON, J. L.; SWAIN, R. S. Metabolism of sulfometuron-methyl in wheat and its possible role in wheat intolerance. J. Agric. Food Chem., v. 40, n. 11, p. 2279-2283, 1992.

AHRENS, W. H. (Ed.). Herbicide handbook. 7.ed. Champaign: Weed Science Society of America, 1994. 352 p.

CALDAS, L. S. et al. Growth-active gibberellins overcome the very slow shoot growth of Hancornia speciosa, an important fruit tree from the Brazilian "Cerrado". Trees, v. 23, n. 6, p. 1229-1235, 2009.

CASTRO, P. R. C. Maturadores químicos em cana-de-açúcar. Saccharum, v. 1, n. 1, p. 12-16, 1999.

CORREIA, N. M.; LEITE, G. J. Selectivity of the plant growth regulators trinexapac-ethyl and sulfometuron-methyl to cultivated species. Sci. Agric., v. 69, n. 3, p. 194-200, 2012.

COSTA, N. V. et al. Características morfológicas de gramas em resposta à aplicação de trinexapac-ethyl.

Planta Daninha, v. 27, n. 1, p. 113-122, 2009.

COX, C. Sulfometuron-methyl methyl (Oust). J. Pestic. Reform, v. 22, n. 4, p. 15-20, 2002.

CURAVIAL. Bula. Disponível em: < http:// www.agricultura.pr.gov.br/arquivos/File/defis/DFI/Bulas/ Outros/CURAVIAL.pdf> . Acesso em: 24 maio 2014.
DALLEY, C. D.; RICHARD JÚNIOR, E. P. Herbicides as ripeners for sugarcane. Weed Sci., v. 58, n. 3, p. 329-333, 2010.

ESPINDULA, M. C. et al. Utilização de redutores de crescimento em trigo. Planta Daninha, v. 27, n. 2, p. 379-387, 2009.

GEYER, W. A.; LONG, C. E. Weed management in plantings of tree and shrub seedlings with sulfometuron methyl (Oust). Trans. Kansas Acad. Sci., v. 101, n. 3/4, p. 120-124, 1998.

HUTCHINSON, P. J.; MORISHITA, D. W.; PRICE, W. J. Season-long dose-response of potato to sulfometuron-methyl. Weed Sci., v. 55, n. 5, p. 521-527, 2007.

INSTITUTO BRASILEIRO DE FLORESTAS - IBF. Eucalipto - Eucalyptus urograndis. Disponível em: <http:// ibflorestas.org.br/loja/semente-eucalipto-urograndis.html> Acesso em: 23 maio 2013.

KAPPES, C. et al. Uso de reguladores de crescimento no desenvolvimento e produção de crotalária. Pesq. Agropec. Trop., v. 41, n. 4, p. 508-518, 2011.

MESCHEDE, D. K. et al. Alteração fisiológica da cana-deaçúcar pela aplicação de glyphosate e sulfumeturon-methyl. Planta Daninha, v. 29, n. 2, p. 413-419, 2011.

MODDUS. Bula. Disponível em: <http:// www.agricultura.pr.gov.br/arquivos/File/defis/DFI/Bulas/ Outros/MODDUS.pdf>. Acesso em: 24 maio 2014.

MOUCO, M. A. C.; ONO, E. O.; RODRIGUES, J. D. Inibidores de síntese de giberelinas e crescimento de mudas de mangueira ‘Tommy Atkins'. Ci. Rural, v. 40, n. 2, p. 273-279, 2010.

NASCIMENTO, V. et al. Uso do regulador de crescimento etil-trinexapac em arroz de terras altas. Bragantia, v. 68, n. 4, p. 921-929, 2009.

NOVO, M. C. S. S.; MIRANDA FILHO, H. S. Tuberização de dois cultivares de batata sob aplicação de sulfoniluréias. Planta Daninha, v. 24, n. 1, p. 115-121, 2006.

PFLEEGER, T. et al. Comparing effects of low levels of herbicides on greenhouse and field-grown potatoes (Solanum tuberosum L.), soybeans (Glycine max L.), and peas (Pisum sativum L.). Environ. Toxicol. Chem., v. 30, n. 2, p. 455-468, 2011.

RADEMACHER, W. Growth retardants: effects on gibberellin biosynthesis and other metabolic pathways. Ann. Rev. Plant Physiol. Plant Molec. Biol., v. 51, n. 1, p. 501-531, 2000.

REMADE. O eucalipto e suas origens. Disponível em: $<$ http://www.remade.com.br/br/revistadamadeira_materia. php?num=20\&subject=Origens\&title $=0 \% 20$ Eucalipto $\% 20 \mathrm{e} \% 20$ Suas\%20Origens>. Acesso em: 12 abr. 2014. 
SOCIEDADE BRASILEIRA DA CIÊNCIA DAS PLANTAS DANINHAS - SBCPD. Procedimentos para instalação, avaliação e análise de experimentos com herbicidas. Londrina: 1995. 42 p.

TAIZ, L.; ZEIGER, E. Plant physiology. 5.ed. Online, 2010. Disponível em: <http://www.plantphys.net>. Acesso em: 12 maio 2014
ZAGONEL, J.; FERNANDES, E. C. Doses e épocas de aplicação de redutor de crescimento afetando cultivares de trigo em duas doses de nitrogênio. Planta Daninha, v. 25, n. 2, p. 331-339, 2007.

ZHOU, Q. et al. Action mechanisms of acetolactate synthaseinhibiting herbicides. Pestic. Biochem. Physiol., v. 89, n. 2, p. 89-96, 2007. 